presses the npinion that, 'expert witnesses ought to be selected hy the court, and should be impartial as well as learned and skilful. A contrary practice, however, is now prohally too well established to allow the more salutary rule to be enforced. Another judge suggests that the law should be so changed 'that th:s class of witnesses should be selected by the court, and that this should be done wholly independent of any nom: nation, recsmmendation, or interference of the parties, as much so to all intents as are the jurors.' This would not make ex perts amici curice any more than before, for all witnesses should be regarded in that light, but it would be a provision rather to preserve that character to them, coupled as it is with a recom mentation as to compensation, so intimately connected $w$ ith it. It is not the fact of extra compen:ation, or that the compensation is paid by the party benefited by his testimony, that creates the unfavourable impression. The o:her witnesies are friends of the court, by whatever pa-ty they may be called, they stand upon the same fosting as to pay; but here is a witness who is paid according to a private agreement, by one of the parties ; the amount is their own private arrangement on which the court is not consulter, over which the court has no control, a circumstance that imparts to him, in high degree, the characler of a friend of one of the parties; and these facts as to compensation are ofien elicited at a time, and in a way, calculated to impair otherwise valuable testimony in the minds of the jury.

"Ry far the best plan seems to be that adopted in the Imperial Courts of Germany. For certain matters and lines of busine.s permanent experts are appointed by the State, but they are nist regarded as officers, but as employ's for the time being. They have no official title, nor regular salary. The payment they receive is not enough to support them, but barely compensates them for their loss of time. For most cases the expert is appointed by the particular judge in the case, often on the demand of one or the other or both parties, but the choice of the expert lies within the discretion of the judge. He may appoint any man whom both parties sugrested, or may also appoint a third man no: suggested hy either, but if both paries unite on one man he must listen to his testimony. If a question is involved for which regular legal experts are provided, these need only be or can he appointed. The qualification; for such a regular expert are that he should follow that particular p:ofession or line of business habitually, and for the purp sse of earning his living. The number of experts in a case is not limited by law, it rests with the discretion of the judge. The status of the expert in court is almost analogou; to other witnesses, but it is not a civic duty, as with witnesses, to give evidence in court except where a profession is followed publicly and for a livelihood. The text of his oath before giving testimony is different from that of an ordinary witness; and he need not be sworn at all if $b$, th parties unite in dispensing with such gualification."

If a similar system were followed in England the testimony of scientific experts would be regarded with a little less suspicion than it is at present. Only by s me such mexns can technicsl evidence of a wholly disinterested character be obtained.

\section{SCIENCE CLASSES IN CONNECTION WITH THE LONDON COUNTY COUNCIL.}

THE Technical Education Board of the London Counly Council has issued a series of Regulations with regard to the administration of grants to science classes. All the preseribed conditions tend to make the instruction efficient and develop technical education in the right direction. The following are those that refer to the manner in which various classes must be conducted :-

(t) That as a condition of aid being granted by the Board for the teaching of chemistry, physics, mechanics, and botany, it wil be regarded as indispensable that provision should be made, to the satisfaction of the Board, not only for the experimenial illus. tration of the lectures or class teaching, but fur experimental work by the students themselves, either in lab ratories bel unging to the institution or, where this cannot be arranged, in the laboratorie; of some neighbouring institution with which the class should be associated ; and ev.ry lecture must be followe by at least one hour's practical work on the same evening, or some other evening in the same week.

(2) Thut with reyard to classes in the subjects comprised in the Science and Art Department Directory which are more s:rictly NO. 1242 , VOL. $4 \delta]$ to be included under the head of technology, viz. building construction and drawing, machine construction and drawing, steam and the steam-engine, navigation and navai architecture, it be required, as a rule, that such classes be taught by teachers having a practical acquaintance with the industries to which they refer; provited that, in the case of teachers who have already succes: fully tatuht such classes, it shall be open to the Board, on being satisfied of the sufficiency of the qualifications, to make exception; in particular cases. No grant will be given fo- classes in agriculture or mining.

(3) That for classes in geology and mineralogy suitable museum specimens be provided and examined by the pupils, and for classes in machine drawing a suitable collection of models and parts of actual machines be provided.

(4) That in the teaching of mathematics, pracicai geometry, building construction, machine drawing, naval architecture, navigation and nautical astronomy, "home work" be made an important feature, and that the students' work be examined and correcied by the teacher out of class hours.

(5) That in all practical laboratory classes, and in classes on mathematic:, pracical yeometry, building con truc ion, mactrine drawing, naval architecture, navigation and nautical astronomy, not more than twen'y stu lents shall be under the charge of one teacher at the same time, but where more than one teacher is present during the whole meeting of the class the number of students may be increased in proportion to the number of teachers.

(6) That in all subjects there be a sufficient supply of appara:u; and $\mathrm{ma}^{+}$erials for efficient teaching, and that such apparatus and materials be $t$ flectively used.

(7) That no payment be made on account of pupils who, in the opinion of the Board, may not reasonably be expected $t$, profit by the teachin $r$ provided (e.g. pupils in navigation or nau ical a-tronomy, or in the advanced stage of theoretical or applied mechanics who have insuff sient knowleilge of mathe matics; those in building construction or machine drawing who have no knowledye of elementary mechanics, \&c.).

The Board is prepared to consider applicalions for assistance to erect laboraturies and provide $t h=$ necessary equipment. It will also make grants in aid of the purchase of apparatus for science teaching. With so many advantages, technical education in the administrative county of London should grow apace.

\section{UNIVERSITY AND EDUCATIONAL INTELLIGENCE.}

THE following is the list of candidates successful in the competition for the IVhitworth Szholarships and Exhibitions, I893:- Scholarships (tenable for three years, having an annual value of $(125)$ :- William Hamilton (Glaigo."), Tohn G. Longbottom (Keighle)), Arthur E. Malpas (London), Richard J Durley (I.ondon); Exhibitions (tenable for one year, having a value of $f_{50}$ ): - Charles F.S ith (Glasgow), John Ball (Derby), William Buchan (Glasgow), John B. Chambers (London), Henry J. Loveridge (Southsea, Portsmouth), William F. Ireland (Glasgow), George W. Fearnley (Shipley), Oliver Styles (Edinburgh), George M. Russell (Portsmouth), Alexander A. Jude (Huli), Elward R. Amor (Devonport), Josepl Jeffery (Birmingham), Paul J. Reynolds (Plumstead, Keni), Thomas Pilkington (London), Richard Reynolds (Cardiff), George Wilson (Sheffield), Walter O. Hammant (Plumstead, Kent), John Orr (Airdrie), William I. Chubb (Londori), Henry Smith (Brighton), Frederick D. Green (Wanstead, Essex), John Powell (Crewr), James H. Hardy (Woodley, near Stockporl), James H. Shepherd (Swindon), Herbert Thompson (Sheffiell), Evan Stevens (Swindon), Henry E. Morrall (Wolverton), Herbert Bates (Manchester), Charles H. Hill (Stratford, London), William F. Massey (Newport, Salop).

The Scholarships Committee of the 185 I Exhibition Science Scholarships has issued a list of appointments for 1893 . Four scholarships awarded in $189 \mathrm{I}$ have been renewed for a thirc year in order to permit the holders to complete their investiga tions. These scholars are James H. Gray, John Joseph Sudborough, Harry Ingle, and Thomas Ewan. The following scholars of 1892 have had their scholarships renewed for a second year:--Andrew John Herbertson, James Blacklock IIenderson, John Macdonald, Lionel Sime n Marks, George Lester Thomas, Hurold Hart Mann, James Terence Conroy, 